\title{
Replacement of floor structures in capital repair with the use of not extractable void formers
}

\author{
Grigoriy Afanasyev* \\ Moscow State University of Civil Engineering, Yaroslavskoe shosse 26, Moscow, 129337, Russia
}

\begin{abstract}
Urgency of the floor structures replacement is driven by the program of capital repair of the residential buildings adopted by the government and stipulates replacement of wood coverings by armored concrete floors that enable increase of stability, fire-resistance and cost effectiveness. Wood partitions and other elements of planning made of materials with low fire-resistance are also subject to replacement.

It has been shown that the use of void formers allows reducing consumption of concrete, reinforcement, reduces duration of building and energy consumption. Thereby the stability and fire-resistance increase of the buildings under renovation is achieved. Solving these tasks is the objective of the represented work.

It is worth noting that when renovating buildings the data about the use of not extractable void formers are absent. The technology development is an author's initiative.

The goal of the investigations consists in analyzing the works of the domestic and foreign scientists that make it possible to assess effectiveness of the technology when erecting buildings of cast in-situ reinforced concrete with the use of void formers.

The submitted work has carried out the adaptation of the works performance technology in confined spaces of capital repair. Optimization of the void formers selection has been made, node points of the slabs' resting on brick walls have been developed, the technology of dismantlement, form work, reinforcing, installation of void formers and concrete pouring has been developed.

The complex of the works provides for obtainment of floor structures with the lesser consumption of concrete and reinforcement..
\end{abstract}

\section{Introduction}

The main reason for the wood coverings replacement of residential and civil buildings is the excessive wear of structures, reduction of the beams' load bearing capacity due to fungosity or rottenness of the supporting portion, fire hazard increase due to the flammable materials use. [1-3] The need for major repairs is also regulated by article 166 of the Housing code of Russian Federation. Apartment building can receive financial support

\footnotetext{
*Corresponding author: gregoria@mail.ru
} 
from the state Corporation "Fund for the development of housing and communal services. To get the money you need to contact the relevant regional authorities. [4-7]

Replacement of floor structures by armored concrete floors is not only an expensive and labor-intensive type of works but introduces certain changes into loads and requires a check of the load bearing capacity of the walls and foundations. Reinforced-concrete floor structures are the most material-intensive structures of the buildings. [8-11]

The idea of usage of not extractable void formers consists in reducing the structures' weight through replacing concrete by them, concrete does not take part in the work, and thereby strength characteristics are not reduced. [12-14]

Innovation - is the introduction of an innovation, which requires additional investments for its implementation. Investing in innovation is a reliable tool to maintain sustainable competitiveness and implemented in all areas of construction activity. [15-17]

Reinforced-concrete floor structures with the void formers can have the bigger load bearing capacity than for solid slabs, and weight is less by $30-40 \%$. There appears an opportunity to overlay big bays, reduction of the structures' total weight attributable to foundation is achieved. [18-19]

Technology of the works performance comprises a preparatory period that is composed of: dismantling elements of the wood covering, partitions, vestibules, with transportation to a stock area; preparation of support points of the coverings on the walls - erection of toothings; installation of slab formwork; supply of reinforcement and manual lashing of frames with installation of void formers; concrete pouring of a concrete floor slab.

They have assessed the technology of building armored concrete floors with not extractable void formers when performing capital repair of the buildings.

To assess effectiveness and processibility of void formers the famous foreign solutions [20-22] have been investigated: COBIAX system (Switzerland) ball-shaped and elliptically contoured void formers; prismatic void formers Nautilus (Spain); BubbleDeck (Canada); Airdeck (USA) - small-size box-section void formers and others.

The result of investigations has established that the most processible void formers are Cobiax system for the replacement conditions of the floor structures in capital repair.

Polystyrene foam slabs of the domestic and foreign production possess of greater effectiveness.

The foreign and domestic construction practice [5,15] uses the technologies of the monolithic floor structures erection with not extractable void formers of different geometric shapes. Their relevance and practical utility are reflected in [22-28].

It is clear that the use of small-size box-section void formers made of polypropylene with the dimensions $20 \times 20 \mathrm{~cm}$ and height 12 to $35 \mathrm{~cm}$ requires big labor efforts, additional control over the geometric position.

Under the factory environment the process of installing void formers is automated.

When manufacturing monolithic floor structures according to BublleDeck system they started using widely not extractable ball-shaped void formers.

According to the data of American company North America LLC, the use of ballshaped void formers enables reduction of concrete consumption to $36 \%$, reinforcement - to $22 \%$, the total reduction of the floor structures' weight is achieved.

\section{Methods}

The analytical and experimental investigations have established that "Cobiax" system that uses linear frames is most effective, into which elliptically contoured or ball-shaped void formers (figure 1) are integrated. 


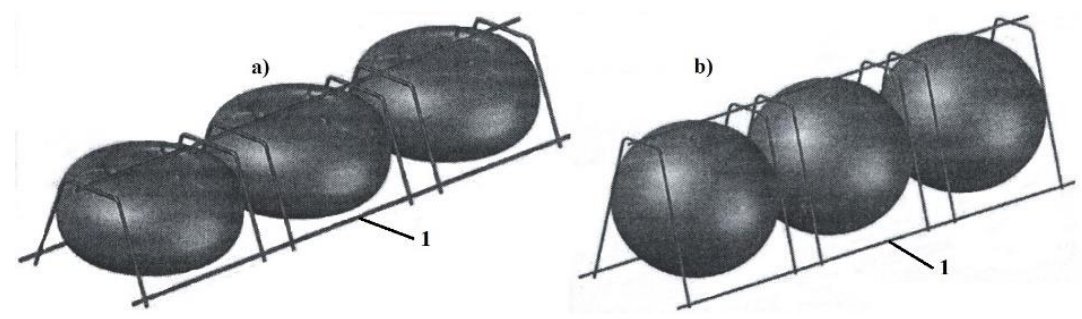

Fig. 1. Modules of void formers. a) - elliptically contoured; b) - ball-shaped; 1 - linear supporting frames.

Such solution allows installing void formers into a design position without additional actions. Void formers are united into separate blocks and modules. Light reinforcement frames made of steel A-III $\varnothing 5 \mathrm{~mm}$ are used for elliptic and ball forms, they fix void formers in a design position. They are united into separate blocks with the area from 0.5 to $3.0 \mathrm{~m}^{2}$.

Dimensions of void formers are selected with due regard to thickness (height) of a slab on design considerations and with due regard to a ratio of the dimensions specified in figure 2.

a)

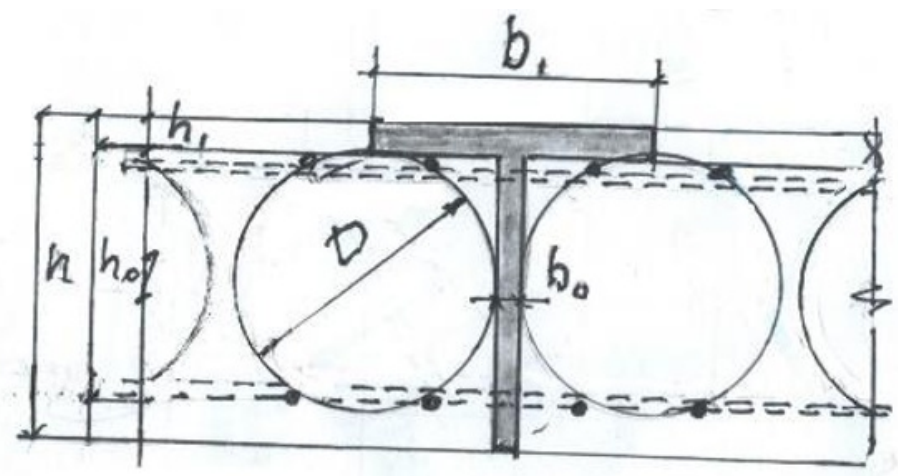

b)

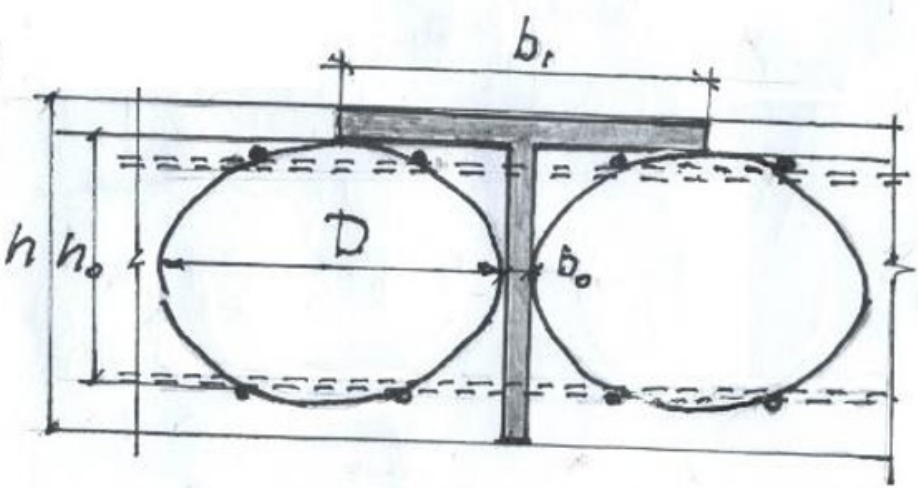

Fig. 2. Ball and elliptic forms of void formers, spacing between them and parameters of floor structures according to Cobiax system

\section{Results and Discussion}

It has been established that elliptically contoured void formers are economically feasible when building interfloor floor structures with the thickness 220-300 mm. Ball-shaped void formers with the thicknesses $380 \mathrm{~mm}$ to $600 \mathrm{~mm}$ are applied. 
To increase the load bearing capacity they use void formers with the diameter $480 \mathrm{~mm}$ and height $210 \mathrm{~mm}$, that are composed of the lower and upper parts. They are assembled at a construction site with the use of the patterns and latches. They are united into modules which are installed into a design position after installation of the lower area's reinforcement (figure 3).

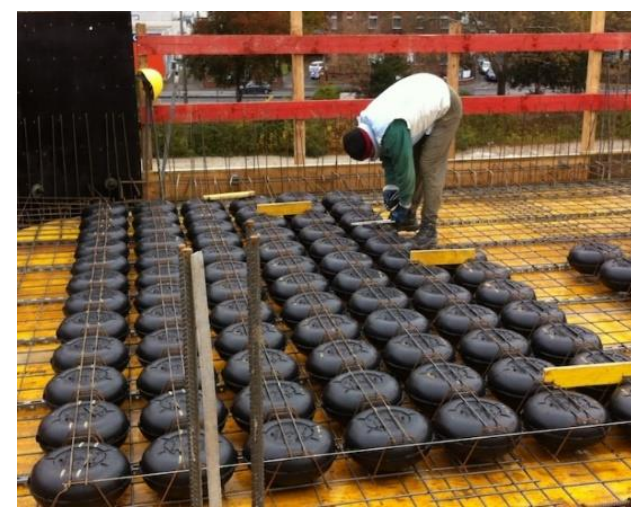

Fig. 3. The work-related issue of installing void formers' modules

The technology of works performance consists in erecting panel formwork, lashing the bottom row with steel with the locks installation, installing modules above pivots of the bottom row, installing the upper working reinforcement above the modules.

A floor structure is made through two-stage concrete pouring. Such method enables excluding a lift-up of form linings. After gain in strength of $1.0-1.5 \mathrm{MPa}$ of the bottom layer, the design position of the modules shall be fixed. Then the second layer shall be poured (figure 4).

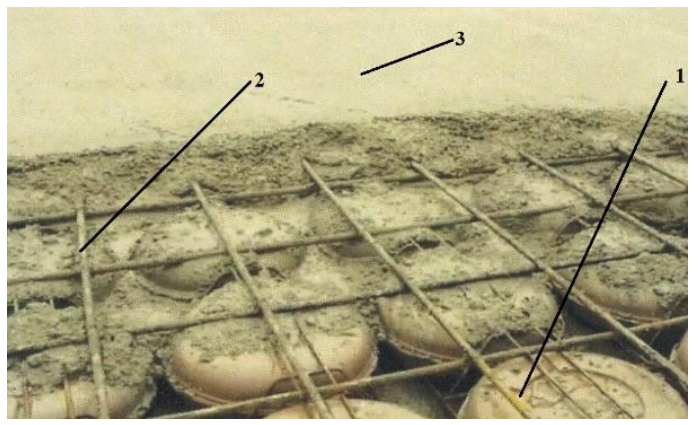

Fig. 4. Grouting floor structures. 1 - hollow form linings; 2 - upper grid reinforcement; 3 - poured and compacted concrete mixture

Elements of floor structures with void formers are meant, as to strength, for the action of moment of flections and torque moments, axial and transverse forces, for local action of the load (static loading, cleavage). Elements of floor structures should take into account forming and opening cracks for all most unsafe cross-sections in above-support and bay areas [25].

When making calculations it should be taken into account that $50 \%$ of the amount of transverse force is perceived in near-support areas. That's why these areas shall be manufactured without void formers, i.e. they shall be manufactured of cast in-situ 
reinforced concrete. Their dimension is identified according to a shearing force diagram (figure 5).

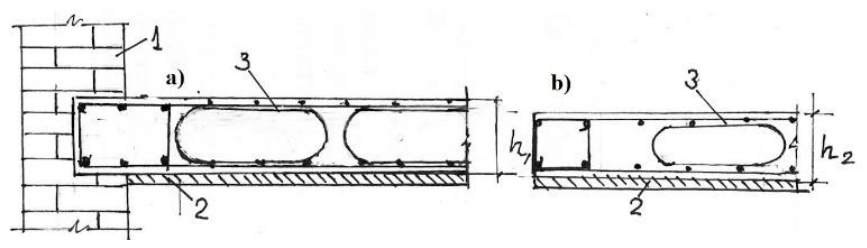

Fig. 5. Scheme of reinforcing of slab's terminal sections: a) in thickness $250 \mathrm{~mm}$ of floor structures;

b) less than $250 \mathrm{~mm} .1$ - brick wall; 2 - bottom; 3- elements forming openings

Increasing processibility of the works performance is achieved through usage of nonextractable void formers from polystyrene foam slabs with the density $30 . .50 \mathrm{~kg} / \mathrm{m}^{3}$. Their low density affects little the weight change of floor structures, but enables reducing concrete consumption that is equal to the volume of form linings [26].

Mass reduction of floor structures with preserving the load bearing capacity is achieved therewith.

The general structural and process scheme of a lightweight floor structure is represented in figure 6.

It includes a lower monolithic reinforced slab, on which polystyrene foam slabs forming longitudinal struts are placed. They are formed as a result of the slabs installation at intervals, including the upper layer of reinforced concrete. Slabs installation is implemented with the patterns use that identify the struts' thickness and height.

Reinforcing and concrete pouring of the lower area of the floor structures shall be made at first. Then slabs shall be installed. To exclude a lift-up they are surcharged, what ensures good adhesion with concrete mixture. Surcharges are removed after concrete has gained the strength of $1.0 \ldots 1.25 \mathrm{MPa}$. Then they reinforce struts, support areas with the design reinforcement cages and slabs' surfaces, with the subsequent pouring concrete mixture.

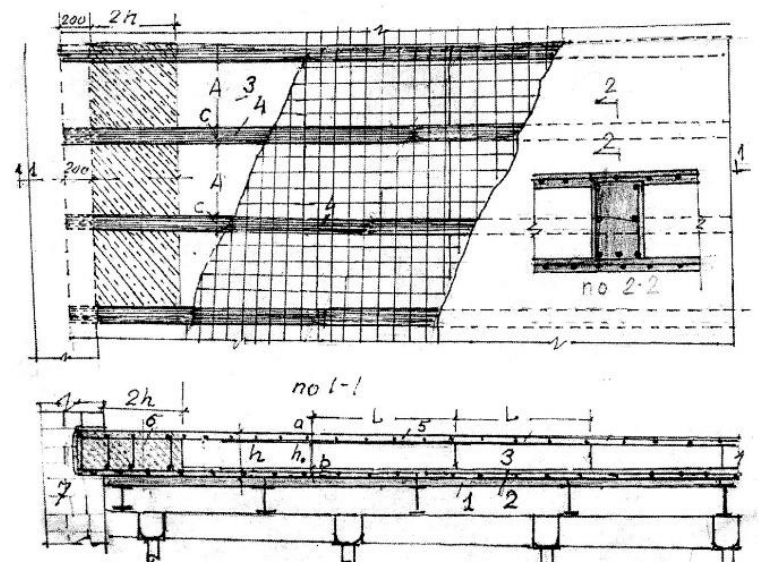

Fig. 6. Process layout of floor structures with polystyrene foam slabs - form linings:

1- bottom; 2 - bottom layer of concrete with few reinforcement; 3 - polystyrene foam slabs;

5 - upper layer of concrete with few reinforcement; 6 - monolithic supporting portion of a slab; 7 - wall with toothing.

Use of high-quality modified concrete mixtures allows receiving stripping strength of the structures at the age of $24-36$ hours (in $R_{\delta}=70-80 \%$ ). 
Technologies with the use of void formers and polystyrene foam slabs enable touching upon the problem of floor structures replacement in capital repair in residential buildings in a novel way. They ensure reducing own weight of floor structures, concrete consumption and reinforcement, what reduces duration and prime cost of the works.

\section{Conclusions}

The technologies of the floor structures replacement in confined spaces of capital repair of the residential buildings have been developed, with the use non-extractable void formers and polystyrene foam slabs that allow increasing reliability, stability and fire-resistance of the buildings, reducing consumption of concrete and reinforcement, reducing works duration by $18-20 \%$, the prime cost of the works performance and total mass of the floor structures, increasing significantly the technical and economic features.

Floor structures possess of greater acoustic insulation, what ensures comfortable conditions of living and operation.

\section{References}

1. Korol, E.A., Kustikova, Y.O. Constructive systems, load-bearing and enclosing structures of high-rise buildings. E3S Web of Conference 2018.

2. Degaev E.N., Orlov A, Pierre El Haddad and Pleshivtsev A. Ecological and Economic Risks of Fire Protection of Warehouses and Tank Parks. MATEC Web of Conferences. 251, 06013 (2018).DOI: https://doi.org/10.1051/matecconf/201825106013.

3. Degaev E.N. New classification of Foaming Agents for Fire Extinguishing. MATEC Web of Conferences. 193, 02032 (2018). DOI: https://doi.org/10.1051/matecconf/201819302032.

4. Polyakova V., Degaev E.,Pierre El Haddad. Reduction of Ecological and Economic Risks in Utilization of Solid Domestic Wastes and Construction Waste. MATEC Web of $\begin{array}{llll}\text { Conferences } & \text { 251, } & 0617 & \text { (2018). }\end{array}$ https://doi.org/10.1051/matecconf/201825106017.

5. Borkovskaya V.G. Project Management Risks in the Sphere of Housing and Communal Services. Journal MATEC Web of Conferences, Volume 251, 06025 (2018). DOI: https://doi.org/10.1051/matecconf/201825106025.

6. BorkovskayaV.G, Passmore D. Behavioral engineering model to identify risks of losses in the construction industry. Book: Smart Technologies and Innovations in Design for Control of Technological Processes and Objects: Economy and Production. Chapter 24. SIST 138, 2018. DOI:10.1007/978-3-030-15577-3_24

7. Borkovskaya V.G., Degaev E., Burkova I. Environmental economic model of risk management and costs in the framework of the quality management system // MATEC Web of Conf., 193 (2018) 05027. DOI: https://doi.org/10.1051/matecconf/201819305027.

8. Korol O., Shushunova N., Lopatkin D., Zanin A., Shushunova T. Application of Hightech Solutions in Ecodevelopment. Journal MATEC Web of Conferences, Volume 251, 06025 (2018). DOI: https://doi.org/10.1051/matecconf/201825106002

9. Korol E.A., Gaydysheva Y., Passmore D. Integration of organizational-technological and social aspects in the realization of the program of renovation of residential development. Journal MATEC Web of Conferences, Volume 251, 06025 (2018). DOI: https://doi.org/10.1051/matecconf/201825106025

10. Korol, E., Pleshivcev, A. Multiple-criteria decision analysis of the transformable lowrise building technological construction process. Matec Web of Conferences 2018. 
11. Korol, E., Mostovoy, D., Pleshivcev, A. Technological parameter optimization of multilayer enclosure structures with the multiple-criteria decision analysis. Matec Web of Conferences 2018.

12. Sokova S.D. Smirnova N.V. Reliability assessment of waterproofing systems of buildings underground parts. IOP Conf. Series: Materials Science and Engineering 365 (2018) 052028 doi:10.1088/1757-899X/365/5/052028

13. Sokova S.D. Smirnova N.V. Innovative technological solutions to ensure the reliability of operated buildings. DOI: https.://doi.org/10.1051/matecconf/201825106018.

14. Kas'yanov V.F. Danilchenko V., Amelin V.,Tolmachev V. Environmental risk management. Forecasting and modeling of emergency risk management. Journal MATEC Web of Conferences, Volume 251, 06030 (2018). DOI: https://doi.org/10.1051/matecconf/201825106030.

15. Borkovskaya V.G. The concept of innovation for sustainable development in the construction business and education. Applied Mechanics and Materials. (Volumes 475476). Chapter 15: Engineering Management. December 2013. Pages 1703-1706. DOI: 10.4028/www.scientific.net/AMM.475-476.1703

16. Borkovskaya V.G. Complex models of active control systems at the modern developing enterprises. Advanced Materials Research (Volumes 945-949). Chapter 22: Manufacturing Management and Engineering Management. June 2014. Pages 30123015. DOI: 10.4028/www.scientific.net/AMR.945-949.3012

17. Borkovskaya V.G. Post bifurcations of the concept of the sustainable development in construction business and education. Advanced Materials Research. (Volumes 860863). Chapter 26: Engineering Education. Pages 3009-3012. December 2013. DOI: 10.4028/www.scientific.net/AMR.860-863.3009

18. Aralov R., Rimshin V. Reinforcement of monolithic reinforced concrete slab with carbon fabrics. In press 2020

19. Kuzina, E., Rimshin, V., Kurbatov, V. The Reliability of Building Structures Against Power and Environmental Degradation Effects. IOP Conference Series: Materials Science and Engineering. 2018

20. Cobiax Technologies A.G. - http://www.cobiax.com/start-seite.

21. Technology Rubbledeck -hhtps:maestro.ru/Novosti/merhduetazhnye-perekrylya-stanntlegkimi-i-ehonomiechnymi.

22. Rubbledeck System- http://.bub-bledeck-un.com/

23. Kudryavtsev A.V., Golovin A.G., The collected works of VII All-Russian conference "Scientific Initiative of Foreign Students and PG students of the Russian Universities", p. 220-225, (2015)

24. Zaitsev Yu.V. Reporter of the Russian Union of Builders, 13, p. 20-21 (2015)

25. Senin N.I., Golovin N.G., Silant'yev A.S. Federal State Budgetary Educational Institution of Higher Professional Education Moscow State University of Civil Engineering, MGSU, p.119, (2014)

26. Egorov P.I.,.Tereza E.A. Scientific sketchbooks of the Pacific National University, p. $187,(2016)$

27. Gil'mutdinova L.R., Golovin N.G. The book of reports of "The Scientific and Technical Conference based on the results of the scientific and research works of the students of the Institute of Construction and Architecture", MGSU, p. 88-90.

28. Glotov D.A., Loskutov I.S., Kantur O.V. Structural mechanics of engineering constructions and structures, 3, p. 66-71, (2012) 